\title{
EFFECTS OF EXPOSURE TIME AND DIETARY OCHRATOXIN A LEVEL ON BROILER PERFORMANCE
}

NEDELJKOVIĆ-TRAILOVIĆ JELENA, JOVANOVIĆ N and SINOVEC Z

Faculty of Veterinary Medicine, Belgrade

(Received 13. June 2004)

The present study was designed to examine the harmful effects of low level ochratoxin A (OTA) for different period and different dietary OTA levels for same period of ingestion as well as to assess the resting period necessary to revoke any adverse effects of OTA. The trial was performed on 72 day-old chickens with 12 broilers in each group. The experimental groups were offered feed contaminated with $0.5 \mathrm{ppm} O A$ during 7, 14 or 21 days in the first evaluation, and feed contaminated with $0.5,1.0$ or $1.5 \mathrm{ppm}$ OTA for 7 days in the second evaluation. The control group $(K)$ received feed free of toxin.

Broilers in the control groups had an average daily gain of $43.5 \mathrm{~g}$ and a feed: gain ratio of $1.97 \mathrm{~kg}$. OTA expressed a negative effect on performance proportion to the time of exposure and to the amount of dietary toxin, showing prolong and cumulative effects. Early detection of OTA and exclusion of contaminated feed could partially prevent its adverse effects, but not less than three weeks of recovery is needed to nullify the damage.

Key words: broilers, ochratoxin A, performance, resting period

\section{INTRODUCTION}

Mycotoxins enter into animal and human organisms mostly through consumption of contaminated feed and food (Ciegler and Vesonder, 1983). Damage to livestock production could be significant. This occurs in the form of direct losses due to an animal's death, or more often it happens indirectly through decreased productive capacity and performance of domestic animals. One of the most important problems is the presence of residues of mycotoxins and their metabolites in various concentrations in the edible tissues of animals fed with contaminated feed indicating possible harmful effects for humans as well.

It is estimated that at least $25 \%$ of the yearly world level of cereals and other grain are contaminated by one or more known mycotoxins (Pasteiner, 1989). Up to now a great number of different mycotoxins has been discovered and described, some of them (aflatoxins, ochratoxins, trichothecenes, zearalenone) with important toxic, nutritional and economic significance. Since the climatic conditions of the Balkan region are optimal for Aspergillus growth, as well as for toxin production, ochratoxin is an abundant and significant mycotoxin. According 
to a recent investigation (cit. acc: Sinovec et al., 2003) ochratoxin A (OTA) is the mycotoxin with the highest prevalence in feeds with an increasing trend. In the 1999 it was established that more than $41 \%$ of positive feed samples contained OTA in amounts above the maximum tolerable levels for different animal species, while in 2000 the rate was above $63 \%$.

Ochratoxin $A$ is a natural contaminant of poultry and livestock feedstuffs. Field outbreaks of ochratoxicosis have been documented (Hamilton et al., 1982), and experimental feeding of OTA has been shown to have detrimental effects on growing chicks (Kubena et al., 1989), indicating that OTA is a potential hazard to poultry producers (Kubena et al., 1985). In recent years ochratoxin A has received considerable attention, not only because it seriously affects animal performance and health, but it may also have deleterious effects on humans. Its implicated role in an irreversible and fatal kidney disease (Balkan endemic nephropathy) is of the greatest concern in humans (Marquardt and Frohlich, 1992).

The toxicity of certain mycotoxins is specific, and the degree of harm depends on the sex, age and species of animals, quality of the ration and the presence of other mycotoxins (Wyllie and Morehouse, 1977). Besides this, the effects of low dietary mycotoxin levels ingested during a long period may be the same as higher intakes during a short period. The present study was, therefore, designed not only to examine the level of OTA in contaminated feed which exerts harmful effects on broiles but also to assess the resting period necessary to revoke its adverse effects.

\section{MATERIALS AND METHODS}

Animals. Hybro broilers were obtained from a commercial hatchery. The trial was performed on 72 day-old chickens with 12 broilers in each group, housed in wire floor battery brooders. Appropriate light-dark cycle, temperature and moisture were maintained throughout the trial.

Diets. All groups of broilers were offered a feed mixture that consisted of standard feedstuffs and contained enough nutrients to satisfy the requirements of this category. The feed for the experimental groups was contaminated with $99 \%$ pure ochratoxin A (Sigma, No O-1877), obtained from Aspergillus ochraceus culture (303-47-9), according to the experimental design.

Experimental design. During the first two weeks of the trials all birds were fed and watered without any treatment.

A total of 48 broilers randomly were divided into three experimental groups $(A, B, C)$ and one control group $(K)$. The experimental groups were offered feed contaminated with 0.5 ppm OTA for 7 (A group), 14 (B group) or 21 (C group) days.

Another 24 broilers were divided randomly into two experimental groups (D, E). During next 7 days the experimental groups were offered feed contaminated with 1.0 or 1.5 ppm OTA, respectively.

Rest period. After the period of toxin administration until the end of the trial $\left(42^{\text {nd }}\right.$ day), birds from all groups in both trials were normally fed and watered without toxin administration. 
Acta Veterinaria (Beograd), Vol. 54, No. 5-6, 419-426, 2004.

Nedeljković-Trailović Jelena et al. Effects of exposure time

and dietary ochratoxin A level on broiler performance

Data and sample collection. Performance and the state of health were monitored during both trials. Body weight (BW) was measured weekly and feed consumption was carefully monitored every day during the trials. From the measured data, the average daily gain (ADG) and gain:feed ratio (GFR) were calculated.

Statistical analysis. All data were statistically processed using Anova, Stat View, MS Excel 97 and Sigma Plot 4.0 software (Snedecor and Cochran, 1971) and an appraisal was made of the significance of differences in mean values between the groups of broilers.

\section{RESULTS AND DISCUSSION}

The performances of the broilers differed between the control and experimental groups, depending upon the duration of toxin ingestion and toxin concentration in the feed. The best performance, reaching the published parameters (Euribird, 1989), typical for the provenience, age and breeding conditions, was achieved by broilers of the control group.

Body weight during the phases of the trials (Table 1) showed that the groups were maximally equalized at the beginning as well as after the pre-treatment period, with no significant differences between them regarding total and average body weight. During the trial, the body weight of broilers in the control group was under the technological limits typical for this provenience. Compared to the control, the groups fed with diets contaminated with OTA achieved a lower body weight, which was correlated to the amount of dietary toxin as well as the duration of toxin ingestion. Statistical appraisal revealed significant $(p<0.05)$ and very significant $(p<0.01)$ differences from the control group.

Thus, it was obvious that OTA expressed a negative effect on body weight, in proportion to the duration of intoxication $(5.88,10.42$ and $14.39 \%)$, as well as to the amount of the toxin in the feed $(5.88,12.24$ and $16.39 \%)$. Our results are in agreement with earlier data (Prior et al., 1979; Ayed et al., 1991), establishing the adverse effects of OTA fed at 0.5 and $1.0 \mathrm{mg} / \mathrm{kg}$ feed on the body weight of broilers. Chang et al. (1981) described a dose dependant decrease in body weight after seven days treatment, whereas Huff et al. (1974) stated that $0.5 \mathrm{mg} / \mathrm{kg}$ OTA in broiler diets had no adverse effect on body weight, even after three weeks treatment.

Broilers receiving the lowest amount of OTA had a significantly lower body weight $(p<0.05)$, compared to the control group, but it was significantly higher $(p<0.05)$ compared to the group receiving the greatest amount of toxin. The three week recovery period was not enough to achieve normal body weight, even with the lowest amounts of OTA. Our results contradict the findings of Ayed et al. (1991) and Prior et al. (1980), describing near body weight equalization of treated broilers after three or more weeks of recovery, when $0.5 \mathrm{mg} / \mathrm{kg}$ OTA was used.

An especially interesting finding was that OTA not only affected body weight during feeding, but also during the beginning of the recovery period, suggesting that OTA expressed a prolonged effect, possibly due to its accumulation. During 

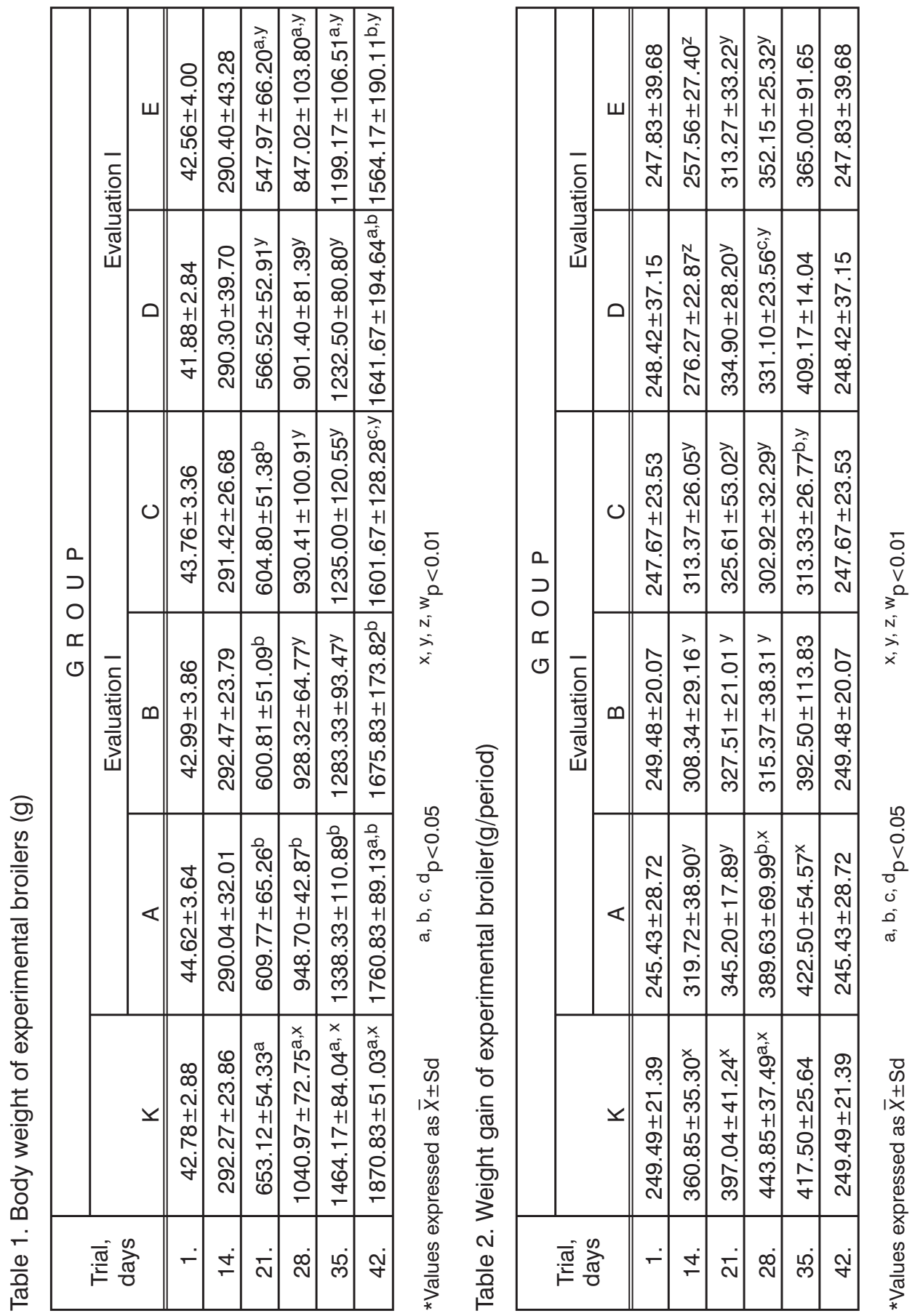
Acta Veterinaria (Beograd), Vol. 54, No. 5-6, 419-426, 2004.

Nedeljković-Trailović Jelena et al. Effects of exposure time

and dietary ochratoxin A level on broiler performance

the later phase of the recovery period, positive effects of OTA catabolism and elimination were observed.

The average daily weight gain during the trials, was similar in the pre-trial period among all groups. During the use of contaminated feed, the experimental groups achieved significantly $(p<0.05)$ and very significantly $(p<0.01)$ lower weight gains, compared to the control and this correlated with the amount of dietary OTA as well as the duration of intoxication (Table 2).

When comparing the experimental groups to the control, it could be concluded that OTA had a negative effect on daily weight gain, correlated to the period of intoxication $(6.11,10.66$ and $14.77 \%)$, as well as to the amount of the toxin in the feed $(6.11,12.48$ and 16.75\%). The decrease was gradual and significant, similar to the results of Prior et al. (1979) and Ayed et al. (1991), indicating that both time of exposure and dietary toxin level expressed similar effects. A recovery period of at least three weeks was needed to normalize the weight gain, although Ayed et al. (1991) described a significantly higher weight gain and faster recovery than in our investigation.

Daily feed intake (Table 3) was influenced by the experimental treatment. Although very similar in the pre-treatment period in both trials, it differed during the use of contaminated feed. Feed intake for the whole trial was proportionally affected by the different durations of intoxication (4.52, 9.03 and 12.56\%). Shortterm use of contaminated feed had a negative effect on daily feed intake, but this was not dependant upon the dose of OTA $(4.52,6.25$ and $4.45 \%)$. Similar results were presented by Prior et al. (1980). After the feed free of OTA was introduced again, the observed differences were diminished. Apparent feed intake seemed to be nearly equal for all the groups, but due to higher loss of wasted feed in the experimental groups, probably as a non-specific way of defense, the actual feed intake calculated after deduction of wasted feed revealed a decreased feed intake.

Table 3. Feed intake of experimental broilers, (g/day)

\begin{tabular}{|c|c|c|c|c|c|c|}
\hline \multirow{2}{*}{ Group } & \multicolumn{7}{|c|}{ Trial, d a y s } \\
\cline { 2 - 7 } & $1-14$. & $14-21$. & $21-28$. & $28-35$. & $35-42$. & $1-42$. \\
\hline \hline K & 28.50 & 90.20 & 107.68 & 133.15 & 137.17 & 87.55 \\
\hline A & 28.75 & 86.32 & 96.16 & 119.11 & 142.44 & 83.59 \\
\hline B & 28.86 & 84.13 & 95.91 & 102.72 & 137.37 & 79.64 \\
\hline C & 28.83 & 85.06 & 95.82 & 92.01 & 116.82 & 76.75 \\
\hline D & 28.92 & 80.51 & 102.86 & 109.26 & 142.04 & 82.08 \\
\hline E & 29.90 & 79.10 & 102.03 & 125.76 & 136.61 & 83.65 \\
\hline
\end{tabular}

Feed gain ratio was clearly under the influence of the applied treatment (Table 4). During the use of contaminated feed, feed: gain ratio in the experimental groups was higher, compared to the control. Although the differences were 
reduced during the rest period, after the replacement of OTA contaminated feed, the negative effects correlated with the duration of toxin ingestion and were proportional to the amount of the toxin ingested cumulatively for the whole trial.

Table 4. Feed:gain ratio of experimental broilers

\begin{tabular}{|c|c|c|c|c|c|c|}
\hline \multirow{2}{*}{ Group } & \multicolumn{7}{|c|}{ Trial, d a y s } \\
\cline { 2 - 7 } & $1-14$. & $14-21$. & $21-28$. & $28-35$. & $35-42$. & $1-42$. \\
\hline \hline K & 1.60 & 1.75 & 1.90 & 2.10 & 2.30 & 1.97 \\
\hline A & 1.64 & 1.89 & 2.02 & 2.14 & 2.36 & 1.98 \\
\hline B & 1.62 & 1.91 & 2.05 & 2.28 & 2.45 & 2.10 \\
\hline C & 1.63 & 1.90 & 2.06 & 2.43 & 2.61 & 2.15 \\
\hline D & 1.63 & 2.04 & 2.15 & 2.31 & 2.43 & 2.15 \\
\hline E & 1.65 & 2.15 & 2.28 & 2.50 & 2.62 & 2.29 \\
\hline
\end{tabular}

Feed gain ratio showed a proportional increase either with prolonged intoxication $(0.51,6.60$ and $9.14 \%)$ or with increased concentrations of OTA $(0.51$, 9.14 and $16.24 \%$ ). The first contact with the contaminated feed, especially when higher doses of OTA were fed (Kubena et al., 1994), acted as a stress factor more intensively than prolonged feeding with lower amounts. Similar results were published by Hamilton et al. (1982), while the report of Chang et al. (1981) was slightly discrepant, because only a high dose of OTA expressed a negative influence on feed: gain ratio.

Ochratoxin has a profound effect on chickens, and it appears to be one of the most potent mycotoxins studied yet, as measured by the minimal growth inhibitory dose. The mechanism whereby OTA exerts its effect in broilers cannot be stated on the basis of the current study. However, it seems to affect several physiological systems. The growth retardation in broilers by OTA at doses as low as $1 \mathrm{mg} / \mathrm{kg}$ suggests that protein-metabolizing systems are impaired. Pitout and $\mathrm{Nel}$ (1969) reported OTA was a competitive inhibitor of carboxypeptidase's A in vitro and proposed a possible inhibitory effect on protein metabolism in vivo. Related to this consideration is the finding that OTA inhibits glycogen utilization in rats probably by competing with 3',5'-cyclic AMP for the enzyme phosphorylase b-kinase (Pitout, 1968). Besides this, OTA competes with phenylalanine for binding sites on the Phe-transfer RNA synthetase enzyme, thus inhibiting protein synthesis (Creppy et al., 1980).

The description of ochratoxicosis signs in broilers has been so incomplete that even a presumptive diagnosis based on symptoms is not possible. This may account for the almost complete lack of knowledge about the severity and extent of ochratoxicosis in the poultry industry. In the absence of symptoms indicative of ochratoxicosis the only recourse has been to employ chemical assays of suspect feedstuffs, but this has been done only rarely because there was little reason to suspect ochratoxicosis. Even if an assay for OTA was performed and the results 
Acta Veterinaria (Beograd), Vol. 54, No. 5-6, 419-426, 2004.

were positive, there remains the difficult question of determining what is a harmful level of OTA.

Early or well-timed establishment of mycotoxin presence in feed and consequent exclusion of contaminated feed from usage could alleviate the negative effects but some period is necessary for the elimination of absorbed mycotoxin (Sinovec et al., 1998). That is why permanent and multilevel monitoring of feed hygiene should be applied in production conditions with the aim of a rapid and efficient response, as this is, for now, the only way for successful prevention of harmful effects. In relation to this, there is also a need to determine the maximum tolerable levels of mycotoxins in the feed for certain species of animals. An absolutely tolerant level is non-existent, since all amounts of dietary mycotoxin could be considered harmful. Moreover, the duration of exposition is an other key factor in the development of adverse effects. A low dietary mycotoxin intakes during a long period has the same effect as high intakes for a short time. Current legislation concerning maximal tolerable amounts of OTA should be corrected, while permanent monitoring of feed quality should be established as the most important measure in mycotoxicosis prevention.

Sumarising the obtained data, it could be concluded that OTA demonstrated negative impacts even in small quantities. These were proportional to the time of exposure, showing prolonged and cumulative effects. Early detection of OTA and exclusion of contaminated feed could partially prevent its adverse effects, but not less than three weeks of recovery is needed to nullify the damage.

Address for correspondence:

Nedeljković-Trailović Jelena, MSc

Faculty of Veterinary Medicine,

Blvd. JNA 18, Belgrade

Serbia \& Montenegro

tjelena@vet.bg.ac.yu

\section{REFERENCES}

1. Ayed M, Dafalla R, Yagi I, Sei A,1991, Effect of ochratoxin A on Lohmann-type chicks, Vet Hum Toxicol, 33, 557-60.

2. Chang F, Dorr J, Hamilton B, 1981, Experimental ochratoxicosis in turkey poults, Poult Sci, 60, 11419.

3. Ciegler A, Vesonder R, 1983, Handbook of food borne disease of biological origin, CRC Press, Florida, USA.

4. Creppy E, Schlegel M, Roschenthaler R, Dirheimer G, 1980, Phenylalanine prevents acute poisoning by ochratoxin A in mice, Toxicol Lett, 60, 77-80.

5. Euribird, 1989 Technical data, The Netherlands, 3-8.

6. Hamilton B, Huff W, Harris J, Wyatt D, 1982, Natural occurrence of ochratoxicosis in poultry, Poult Sci, $61,1832-41$.

7. Huff E, Wyatt D, Tucker L, Hamilton B, 1974, Ochratoxicosis in broiler chickens, Poult. Sci, 67, 113942.

8. Kubena F, Harvey B. Edrington S, 1994, Influence of ochratoxin A and diacetoxyscirpenol singly and in combination on broiler chickens, Poult Sci, 73, 408-15. 
9. Kubena F, Harvey B, Fletcher J, Phillips D, Mollenhauer H, Witzel A, Heidelbaugh D, 1985, Toxicity of ochratoxin A and vanadium to growing chicks, Poult Sci, 64, 620-28.

10. Kubena F, Harvey B, Huff E, Corrier E, Phillips D, Rottinghaus GE, 1989, Influence of ochratoxin A and T-2 singly and in combination on broiler chickens, Poult Sci, 68, 867-72.

11. Marquardt $R$, Frohlich $A$, 1992, A review of recent advances in understanding ochratoxicosis, $J$ Anim Sci, 70, 3968-88.

12. Pasteiner S, 1998, Mycotoxins in animal husbandry, Biomin Gesunde Tierernahrung Int. GesembH, Wien, Austria.

13. Pitout J, Nel W, 1969 The inhibitory effect of ochratoxin A on bovine carboxypeptidase A in vitro, Biochem Pharmacol, 18, 1837-43.

14. Pitout J, 1968, The effect of ochratoxin A on glycogen storage in the rat liver, Toxicol Appl Pharmacol, 13, 299-306.

15. Prior G, Sisodia S, O Neil B, 1976, Acute oral ochratoxicosis, in day-old White leghorns turkeys and Japanese quail, Polt Sci, 55, 786-8.

16. Prior M, O’Neil B, Sisodia S, 1980 Effects of ochratoxin A on growth response and residues in broiler. Poult Sci, 59, 1254-57

17. Sinovec Z, Nedeljković-Trailović J, Sinovec S, 1998, Importance of ochratoxin in poultry nutrition, Biotechnology in Animal Husbandry 14, 5-6, 33-42.

18. Sinovec Z, Resanović R, Sinovec S, 2000, Presence, effects and prevention of mycotoxicosis, Biotechnology in Animal Husbandry, 19, 345-56.

19. Snedecor WG, Cochran GW, 1971, Statistical Methods. The lowa State Univ Press.

20. WyllieT, Morehouse L, 1977, Mycotoxic fungi, Mycotoxins, mycotoxicosis, An Encyclopedic Handbook, vol 2, Marcel Dekker, INC, New York

\title{
EFEKTI DUŽINE EKSPOZICIJE I SADRŽAJA OHRATOKSINA A U HRANI NA PROIZVODNE REZULTATE BROJLERA
}

\author{
NEDELJKOVIĆ-TRAILOVIĆ JELENA, JOVANOVIĆ N i SINOVEC Z
}

\section{SADRŽAJ}

Cilj rada je bio da se utvrde količine OTA u hrani koje izazivaju neželjene efekte sa aspekta doze i dužine ekspozicije, kao i da se utvrdi vreme odmora nakon zamene kontaminirane hrane potrebno za povlačenje tih efekata.

U prvom ogledu su brojleri nakon dve nedelje pripreme dobijali 0,5 ppm OTA tokom 7, 14 ili 21 dan. U drugom ogledu brojleri su dobijali 0,5, 1,0 ili 1,5 ppm OTA tokom 7 dana. Kontrolna grupa $(\mathrm{K})$ je dobijala hranu bez toksina.

Brojleri kontrolne grupe su postigli dnevni prirast od $43.5 \mathrm{~g}$ uz konverziju hrane od $1.97 \mathrm{~kg}$. Ohratoksin je ispoljio negativne efekte na proizvodne rezultate proporcionalno dužini unošenja i količini u hrani, ispoljavajući protrahirano i kumulativno dejstvo. Rana detekcija prisustva OTA u hrani i isključivanje kontaminirane hrane može delimično da prevenira štetne efekte, ali je neophodan odmor od bar tri nedelje da se oni ublaže. 